neofilolog

Czasopismo Polskiego Towarzystwa Neofilologicznego

ISSN 1429-2173, elSSN 2545-3971, 2021, NR 57/1, 67-77

http://dx.doi.org/10.14746/n.2021.57.1.5

http://poltowneo.org/

\author{
Monika Szymańska \\ Uniwersytet Warszawski \\ https://orcid.org/ 0000-0002-4405-1825 \\ m.szymanska1994@gmail.com
}

\title{
Nauczanie podsystemu leksykalnego w edukacji przedszkolnej dzieci ze spektrum autyzmu oraz zespołem Aspergera
}

\section{Lexical repertoire teaching in preschool education of the children with autism spectrum disorder and Asperger syndrome}

Not only special educational needs, but also developmental traits strongly determine the specificity of lexical repertoire teaching process of foreign language in preschool education. The aim of this paper is to present the results of a study carried out among a group of 5 -year-old autistic and Asperger children. The purpose of this particular pedagogical context of preschool education is to discuss some difficulties and their feasible modifications into methodical possibilities. First of all, with the aid of neurobiological perspective the specificity of lexical repertoire teaching among children will be presented. Furthermore, particular needs and abilities of the children with autism spectrum disorder and Asperger syndrome will be discussed. The practical part of this paper was based on a research conducted in 2018/2019 in Warsaw. The study enabled us to diagnose whether the application of the multiple intelligences' theory, the multisensorial tasks and the didactic game in the context of preschool special education affects the learning - teaching process of the foreign language

Keywords: lexical repertoire teaching, special educational needs, preschool education, foreign language

Słowa kluczowe: nauczanie podsystemu leksykalnego, specjalne potrzeby edukacyjne, edukacja przedszkolna, język obcy 


\section{Wstęp}

W ostatnich latach obserwuje się tendencję do coraz wcześniejszego rozpoczynania przez dzieci nauki języków obcych. Ma to swoje uzasadnienie w przekonaniach o plastyczności mózgu i, w związku z tym, możliwości lepszego opanowania przez maluchy obcojęzycznej wymowy, a także sprawniejszego przyswajania przez nie słownictwa dzięki pełniejszemu zaangażowaniu prawej półkuli (Kic-Drgas, 2015: 36). Nauczanie języków na tak wczesnym etapie edukacyjnym to proces złożony, wymagający odpowiedzialnego doboru metod współgrających z potrzebami oraz cechami rozwojowymi dzieci. Praca najczęściej koncentruje się na rozwijaniu znajomości podsystemu leksykalnego, który ma stanowić rodzaj fundamentu dla przyszłej nauki.

Szczególną grupą uczących się są dzieci o specjalnych potrzebach edukacyjnych, w tym ze spektrum autyzmu oraz zespołem Aspergera. Dzieci te charakteryzuje niestandardowy typ uwagi, potrzebują też, również podczas nauki, zachowań rutynowych. Lekcje dla nich powinny być więc skonstruowane w sposób niezwykle precyzyjny i przemyślany, a nauczyciel musi operować konkretami, unikając wszelkich uogólnień. Autyści nie posiadają umiejętności tłumaczenia swojego toku myślenia, a ich kreatywność bywa ograniczona (Mottron, 2010: 56). Przy wielu trudnościach posiadają jednak zespół szczególnych umiejętności, wyróżniających je spośród dzieci bez zaburzeń.

Kontekst nauczania języka obcego dzieci ze specjalnymi potrzebami edukacyjnymi na etapie przedszkolnym rzadko poddawany jest pogłębionym badaniom na gruncie glottodydaktyki. Wynika to ze zróżnicowanego profilu dzieci i rozległości objawów możliwych w spektrum autyzmu. W celu wypełnienia powstałej luki, w roku szkolnym 2018/2019 zdecydowano się na zrealizowanie badania w jednym z niepublicznych przedszkoli integracyjnych językowo-muzycznych w Warszawie. Obejmowało ono szesnaście jednostek lekcyjnych i dotyczyło grupy dzieci pięcioletnich. Podczas planowania przebiegu badań zostały wykorzystane wieloletnie doświadczenia zebrane podczas pracy z uczniami autystycznymi, a uzyskane wyniki wyraźnie pokazują, że można skutecznie minimalizować trudności małych uczniów i tak dopasowywać istniejące metody do ich potrzeb, by osiągnąć sukces pedagogiczny.

\section{Nauczanie podsystemu leksykalnego uczniów w wieku przedszkolnym}

Koncepcje kursu językowego różnią się w zależności od wieku uczących się. W przypadku dzieci poniżej 10. roku życia zarówno cele nauczania, jak i metody pracy determinowane są przez ich cechy rozwojowe. Jak trafnie zauważa Komorowska (2005: 37), nauka języka obcego u dzieci powinna być widziana 
Nauczanie podsystemu leksykalnego w edukacji przedszkolnej dzieci ze...

raczej jako rodzaj przygotowania językowego o funkcji motywacyjnej niż kształcenie językowe per se. U czniowie w tym wieku nie potrafią bowiem jeszcze swobodnie posługiwać się językiem pisanym, młodsi często nie rozpoznają liter ani cyfr. Jednocześnie cechuje ich ogromna potrzeba ruchu, a także niezwykła pamięć słuchowa․ Potrafią zapamiętać słowa już po jednej ekspozycji, ponieważ podświadomie wykorzystują do tego technikę fast mapping ${ }^{2}$. Stąd celem większości kursów w przedszkolu jest przede wszystkim rozwijanie znajomości słownictwa (zob. Tiefenthal, 2008). Najczęściej proponuje się rzeczowniki, w mniejszym stopniu czasowniki i przymiotniki, wszystkie zawsze skontekstualizowane i dotyczące konkretnych przedmiotów lub czynności (Vanthier, 2009: 22). Nauczanie zasobów leksykalnych na samym początku nauki jest także uwarunkowane względami praktycznymi. Blokada komunikacji najczęściej powstaje w skutek niewystarczającego opanowania zasobu leksykalnego. Jak wykazują Milton i Alexiou (2009), aby osiągnąć przejście pomiędzy poziomem A1 a A2 potrzeba znajomości 1500 słów, przejście na poziom B1 natomiast wymaga kolejnego ich 1000. Wczesna ekspozycja na szerokie zasoby leksykalne w języku obcym i skuteczne ich przyswajanie wpływa zatem na sukces w nauce na kolejnych poziomach i zwiększa motywację do pracy (Alexiou, Milton, Roghani, 2019: 155).

Aby w pełni zrozumieć koncepcję nauczania językowego w przedszkolu, należy rozpocząć rozważania od dwóch podstawowych założeń. Po pierwsze, edukacja i wychowanie stanowią, jak zauważa Piotrowska-Skrzypek (2015: 23), nierozłączny duet. Na tym etapie rozwojowym przedszkolny opiekun dziecka staje się na kilka godzin substytutem rodzica. M usi zatem łączyć obie te role i skutecznie przekazywać wiedzę na temat otaczającej malucha rzeczywistości językowo-kulturowej. Po drugie, wszystkie dzieci są zdolne. Z perspektywy neurobiologicznej jest to wynikiem istnienia licznych połączeń neuronalnych, charakterystycznych jedynie dla młodego organizmu. Jak podkreślają Hüther i Hauser (2014), wczesna edukacja powinna cechować się wszechstronnością, by jak najwięcej z tych połączeń zostało zachowanych.

Dobierając pomoce dydaktyczne do zajęć, należy pamiętać o konieczności wykorzystywania materiałów wizualnych. Stanowią one doskonałe uzupełnienie komunikatu językowego, wspomagają rozumienie i utrwalanie nie

\footnotetext{
${ }^{1}$ Z zajęć, co oczywiste, należy zatem wyeliminować zarówno odwołania do tekstów, jak i prowadzenie notatek w zeszytach.

${ }^{2} \mathrm{~W}$ psychologii poznawczej szybkie mapowanie jest terminem stosowanym do hipotetycznego procesu mentalnego, w którym nowa koncepcja jest przyswajana tylko w oparciu o minimalną ekspozycję na daną jednostkę informacji (zob. https://en.wikipedia.org/wiki/Fast_mapping).
} 
tylko słownictwa, lecz także wykorzystywanych podczas lekcji struktur (SowaBacia, 2019: 76). Nie należy wystrzegać się także materiałów wideo, przeznaczonych dla młodych natywnych użytkowników. Bajki ze znanej serii Peppa Pig stanowią doskonałą okazję do kontekstualizacji wprowadzanego słownictwa i kształtowania umiejętności rozumienia ze słuchu (Alexiou, Milton, Roghani, 2019: 156). W podobny sposób wykorzystywać można czytanie książek. Zaleca się, aby były to historie dobrze znane dzieciom, by nie musiały one całej uwagi poświęcać fabule i miały okazję do wsłuchiwania się w słownictwo.

Skuteczność edukacji przedszkolnej uzależniona jest od elastyczności i świadomości nauczyciela, który podczas planowania i realizacji zajęć musi uwzględniać cechy rozwojowe swoich podopiecznych. Małe dzieci pozbawione są myślenia logicznego i abstrakcyjnego, cechuje je natomiast myślenie konkretne i pamięć mechaniczna. Szybko zapamiętują nowe elementy, lecz bardzo szybko je zapominają, dlatego też niezbędnym komponentem zajęć jest częste powtarzanie i utrwalanie poznawanego przez nie słownictwa. Stała potrzeba ruchu i aktywności fizycznej oznaczają dla nauczyciela częste zmiany proponowanych aktywności i ich różnicowanie. Najmłodsi uczestnicy zajęć często również nie nawiązują kontaktu z uczącym, który może odczuwać zniechęcenie. Jest to jednak typowa reakcja na kontakt z językiem obcym: dziecko podejmuje aktywność, gdy odczuwa gotowość, by to zrobić. Warto więc zrezygnować z odpowiedzi indywidualnych, na rzecz wspólnych powtórzeń i imitacji rozmaitych głosów. Warto też pamiętać, że ćwiczenie wymowy, intonacji i rytmu na nowo poznawanych strukturach leksykalnych pozwoli dzieciom na lepsze opanowanie podsystemu fonetycznego, a w przyszłości na niezaburzoną interakcję z innymi użytkownikami.

\section{Zdolności i potrzeby osób ze spektrum autyzmu oraz zespołem Aspergera}

Autystyczne spektrum zaburzeń obejmuje szeroki profil neurobehawioralnych nieprawidłowości w rozwoju (Wolski, 2013: 45). Dotyczą one trudności zzakresu zachowań społecznych, komunikacji, a także specyficznych sztywnych wzorców aktywności i zainteresowań. Osoby ze zdiagnozowanym spektrum autyzmu mają ograniczoną zdolność do tworzenia relacji z innymi i uczestniczenia w interakcjach społecznych oraz charakteryzują się, jak pisze Pisula (2010), ograniczonym repertuarem aktywności, wynikającym częściowo z braku wyobraźni. Mimo licznych trudności i ograniczeń w ogólnym funkcjonowaniu społecznym, autyści, jak zauważa Mottron (2004: 135) „traktowani jako osoby niepełnosprawne, postrzegani są jako posiadający coś mniej niż nie-autyści. Tymczasem [...] są to osoby inne, przyrównywane do norm dla osób bez zaburzeń". Autyzm powinien być zatem postrzegany jako unikatowość, umiejętność spojrzenia na świat w inny sposób i odmiennego w nim funkcjonowania. 
Nauczanie podsystemu leksykalnego w edukacji przedszkolnej dzieci ze...

Osoby ze spektrum posiadają normalny, a czasem nawet wyższy poziom inteligencji niż osoby bez zaburzeń. Jako dzieci dużo szybciej opanowują zdolności pisania i czytania, a dzięki fiksacjom tematycznym posiadają ogromną wiedzę z zakresu nietypowych kategorii (Dufrêne, Chambres, Chambres, 2009: 60). Ich pamięć długotrwała jest niezwykle rozwinięta, dlatego z ogromną precyzją odtwarzają wydarzenia z dzieciństwa lub fragmenty przeczytanych niegdyś książek. Zawdzięczają ją także nietypowemu rodzajowi myślenia, opartemu na obrazach zamiast słów. W kontekście społecznym są szczerymi i wiernymi przyjaciółmi o specyficznym poczuciu humoru.

Mimo tak szerokiego wachlarza cech pozytywnych, autyści na co dzień mierzą się z trudnościami w funkcjonowaniu społecznym. Brak umiejętności wchodzenia w interakcje z innymi oraz rozumienia i stosowania zasad czy kodów skutkuje częstą izolacją i samotnym spędzaniem czasu (Dufrêne, Chambres, Chambres, 2009: 63). Ich ograniczone, lecz bardzo rozwinięte zainteresowania oraz umiejętności pogłębiają dodatkowo tę tendencję. Ponadto osoby te często tworzą rutynowe wzorce zachowań, które trudno im przełamać, narzucają je też otoczeniu. Często w momentach eskalacji emocji stosują technikę autostymulacji sensorycznej lub angażują sztywne wzorce zachowań, wprowadzając siebie lub przedmioty wokół w ruch wirowy, podskakując lub wykonując inne, specyficzne ruchy całym ciałem (Wolski, 2013: 49). Na poziomie językowym odznaczają się nietypową intonacją i wyrafinowanym doborem słownictwa oraz struktur gramatycznych. Dostrzegalny jest jednak duży rozdźwięk pomiędzy umiejętnościami produktywnymi a receptywnymi, które sprawiają im wiele trudności. Autyści często wykorzystują w komunikacji także stereotypie językowe, odwołując się do znanych im, utrwalonych na stałe struktur. Domagają się wielokrotnego powtarzania tych samych historii, czytania czy oglądania tych samych bajek (Wolski, 2013: 52).

Szczególne potrzeby i zdolności osób ze spektrum powinny zostać odpowiednio wykorzystane podczas zajęć językowych. Do zadań nauczyciela należy z pewnością powtarzalna organizacja czasu pracy. Zapewnia to uczniom poczucie bezpieczeństwa i umożliwia pełniejszą integrację ze środowiskiem. Ponadto, podstawowym aspektem wymagającym adaptacji jest sposób wypowiadania się i przekazywania informacji. Słowa, szczególnie te w języku obcym, powinny być wspierane przekazem wizualnym, sam język musi być natomiast prosty, konkretny i powtarzalny (Ministère de l'éducation nationale, 2009: 24). Używanie długich, skomplikowanych zdań okazuje się dla uczniów demotywujące i wpływa na spadek skupienia uwagi. Nauczyciel może zatem 'wyposażyć' dzieci w rodzaj podręcznych zwrotów, których będzie używał podczas formułowania poleceń.

Wśród strategii pedagogicznych dopasowanych do potrzeb osób ze spektrum wyróżnia się m.in. odkrywanie ich zainteresowań i motywacji. W tym 
celu należy nawiązać kontakt z rodzicami i ustalić, co sprawdza się w przypadku pracy z konkretnym dzieckiem. Jak napisano w broszurze stworzonej przez francuskie M inisterstwo Edukacji Narodowej (2009: 25), w celu ułatwienia realizacji ćwiczeń warto wspierać ucznia gestami i sprawdzać, czy jego wzrok skierowany jest na proponowane materiały, autyści mają bowiem problem z koordynacją wzrokowo-przestrzenną, co wyraża się poprzez tracenie koncentracji. Wprowadzane treści należy poddać skrupulatnej strukturyzacji, w taki sposób, by każde kolejne ćwiczenie wprowadzało tylko jedną nową trudność. Zadania oparte na rywalizacji nie sprawdzą się w przypadku osób o specjalnych potrzebach edukacyjnych, ponieważ nie mają one potrzeby porównywania się z innymi. Punktem wyjścia do planowania aktywności powinny być zatem zawsze indywidualne motywacje uczniów.

\section{Praktyczne rozwiązania metodyczne wynikające z badania}

W roku szkolnym 2018/2019 w jednym z warszawskich niepublicznych przedszkoli integracyjnych językowo-muzycznych przeprowadzono badanie, którym objęto grupę dzieci pięcioletnich o specjalnych potrzebach edukacyjnych. Podzielono je na trzy etapy, z których pierwszy obejmował obserwację grupy podczas zajęć językowych prowadzonych według znanego im schematu. Następnie rozpoczęto zbieranie informacji o dzieciach na podstawie wywiadów z wychowawcami oraz analiz orzeczeń o potrzebie kształcenia specjalnego z poradni psychologiczno-pedagogicznych. W ostatnim etapie obserwowano grupy podczas zajęć prowadzonych z wykorzystaniem zadań multisensorycznych, zabawy, a także teorii inteligencji wielorakich Gardnera. Celem badań było sprawdzenie, jak zastosowanie nowego rozwiązania dydaktycznego wpłynie na opanowanie słownictwa przez dzieci oraz czy zmieni się ich nastawienie do zajęć. Zgodnie z hipotezą, praktyka pedagogiczna wykorzystująca koncepcję inteligencji wielorakich Gardnera, zadania multisensoryczne oraz zabawę poprawia nastawienie dzieci do zajęć, wpływa na zmniejszenie częstości występowania momentów krytycznych oraz wzmaga autonomię uczniów. ćwiczenia wprowadzone do badań dopasowano do specjalnych potrzeb edukacyjnych uczestników, biorących w nim udział.

W wyniku badania zaobserwowano znaczną poprawę dotyczącą nastawienia dzieci do zajęć. U 90\% badanych uczniów udało się wyeliminować występowanie incydentów krytycznych spowodowanych eskalacją negatywnych emocji. U 66\% badanych zmianie uległy także ich przyczyny, które nie obejmowały już lęku przed porażką czy współpracą w grupie, dotyczyły jedynie doświadczeń niezwiązanych z zajęciami, np. samopoczucia. W rezultacie dzieci chętniej wykonywały proponowane zadania, wykazywały się większym skupieniem i chęcią 
Nauczanie podsystemu leksykalnego w edukacji przedszkolnej dzieci ze...

współpracy. Zwiększenie efektywności w przyswajaniu proponowanych treści zaobserwowano także wśród dzieci bez zaburzeń. Poniżej zaprezentowano przykładowe rozwiązania wdrażane podczas badań.

\subsection{Zadania multisensoryczne}

Dzieci w wieku przedszkolnym to specyficzna grupa uczniów, cechująca się równie szybkim zapamiętywaniem nowych treści, co ich zapominaniem. Ze względu na tę właściwość, proponowane aktywności powinny być krótkie i zróżnicowanie, by stymulowały różne zmysły. W schemat potrzeb dzieci o specjalnych potrzebach edukacyjnych doskonale wpisuje się wykorzystywanie podczas zajęć zadań multisensorycznych. Integrują one zarówno słuch, smak, wzrok i dotyk, jak i intensyfikują doznania odbierane przez obie półkule mózgowe (Wierzchosławska, 2018: 49). Jak zauważa w swoich rozważaniach Konderak (2017: 98), działania takie sprzyjają naturalnemu poznawaniu świata, znacząco wpływają też skuteczność przyswajania podsystemu leksykalnego, informacje przesyłane do kory mózgowej za pomocą różnych kanałów sensorycznych są bowiem trwalej zapamiętywane (Kotarba-Kańczugowska, 2010: 44).

Nauczanie multisensoryczne realizowane jest w dwóch etapach, z których pierwszy polega na wielozmysłowym w prowadzaniu nowego słownictwa. W ramach badań dzieci miały okazję, na przykład, obcować z kwiatami oraz nasionami roślin, których nazwy poznawały. Ich zadaniem było przyglądanie się materiałowi oraz dopasowanie go do ilustracji roślin. Następnie obrazki były klasyfikowane według trzech kategorii: koloru, liczby sylab oraz pierwszej litery. Okazało się to bardzo przydatne w kontekście specjalnych potrzeb edukacyjnych autystów biorących udział w badaniu. Klasyfikacja i uporządkowanie materiału zapewniły im poczucie bezpieczeństwa i regularności działań. Drugim etapem nauczania multisensorycznego jest utrwalanie wprowadzanego materiału umożliwiające integrację doznań zmysłowych oraz wpływające na odpowiednie przetwarzanie informacji. W tym celu prowadzący rozkładał przed uczniami ilustracje, następnie wskazywał je kolejno za pomocą różdżki, wypowiadając ich nazwy. Użycie wskaźnika eliminuje problemy z koordynacją wzrokowo-przestrzenną dzieci, natomiast odwołania do ilustracji porządkują proces nauczania. Zadaniem uczniów była obserwacja ruchów różdżki, słuchanie słów nauczyciela i powtarzanie. Dzięki powtarzaniu grupowemu, uczniowie nie obawiają się porażki, co skutecznie eliminuje eskalację negatywnych emocji i narastanie schematyzmu ruchowego. Gdy nauczyciel popełnił błąd, zadaniem dzieci było wskazanie prawidłowej reprezentacji leksykalnej. Jak trafnie zauważa Wierzchosławska (2018: 49), dzięki aktywnemu stylowi przyswajania, dzieci rozwijają podczas zajęć umiejętność współpracy 
w grupie i budowania relacji rówieśniczych, co jest szczególnie istotne w przypadku uczniów o specjalnych potrzebach edukacyjnych.

\subsection{Zabawa}

Zabawa pełni w rozwoju dzieci bardzo ważną funkcję, bowiem wspiera nabywanie umiejętności niezbędnych w życiu dorosłym. Ze względu na swoją rangę powinna zatem stanowić podstawowe medium przekazywania treści podczas zajęć w przedszkolu, nie tylko tych językowych, lecz także edukacyjnych. Aby przynosiła ona oczekiwane rezultaty, powinna być, jak pisze Cichmińska (2015: 14), swobodnym wyrazem wolności, przyjemnością, aktywnością pozbawioną stresu i napięcia. Według M ediny (2010), dzięki zabawie dzieci rozwijają wyobraźnię, stają się twórcze i śmiałe, a także lepiej zapamiętują. Ze względu na te cechy stanowi ona doskonałe medium przekazu podsystemu leksykalnego dla dzieci, także tych o specjalnych potrzebach edukacyjnych.

Według Wójcik-Gugulskiej (2017: 104) wykorzystywanie podczas zajęć różnych rodzajów gier dostępnych na rynku wspiera motywacje uczniów do aktywnego uczestnictwa w zabawie. Na potrzeby badań zdecydowano się na modyfikację popularnej gry Twister. Na planszy rozłożono koperty z zadaniami, do których dostęp uzyskiwało się po odgadnięciu ilustracji z leksyką z odpowiedniej kategorii kolorystycznej. Dzieci losowały kartkę z kolorem, wybierały obrazek z odpowiedniej kategorii i zadawały pytanie pełnym zdaniem, by otrzymać odpowiedź również pełnym zdaniem. Wtedy uzyskiwały możliwość wykonania zadania z jednej z kopert danego koloru:

- w kopertach oznaczonych "<>, znajdowały się karty do gry, które należało uporządkować rosnąco (strzałka w górę) lub malejąco (strzałka w dół);

- w kopertach oznaczonych "?" znajdowała się jedna karta; jedno z dzieci zaglądało do środka, a zadaniem reszty grupy było odgadnięcie numeru na karcie z wykorzystaniem odpowiedniej struktury;

- $\quad$ w kopertach oznaczonych +- =znajdowały się karty, z których należało ułożyć działanie matematyczne.

Dzieci chętnie uczestniczyły w zadaniu, w którym każdorazowo wprowadzono jedną nową trudność. Sprzyjało ono zachowaniu struktury przyjaznej uczniom o specjalnych potrzebach edukacyjnych i wspomagającej utrwalanie słownictwa. Niektórzy z objętych obserwacją uczestników eksperymentu podjęli się modyfikacji aktywności. Jak zauważa Cichmińska (2015: 14), należy pozwolić dzieciom na urozmaicanie zabaw, zwłaszcza tych, w których czują się pewnie. 
Nauczanie podsystemu leksykalnego w edukacji przedszkolnej dzieci ze...

\subsection{Teoria Howarda Gardnera}

Gardner (1983), szukając odpowiedzi na pytanie Czym jest inteligencja?, zdefiniował ją jako zdolność do rozwiązywania problemów. Stwierdził też, że człowiek nie posiada jednej inteligencji, lecz rozwija osiem jej typów, nazywanych przez niektórych naukowców zdolnościami (Kondrat, 2011: 2). Wśród typów inteligencji badacz wyróżnił: logiczno-matematyczną, językową, przyrodniczą, muzyczną, przestrzenną, kinestetyczną, intra- i interpersonalną. Inteligencje te nie funkcjonują w izolacji, lecz wzajemnie się uzupełniają, tworząc jednostkowe konstelacje. Wykorzystanie ujęcia Gardnera owocuje tworzeniem zróżnicowanych aktywności ukierunkowanych na różne rodzaje inteligencji, co wpływa na zwiększenie efektywności procesu nauczania, w tym opanowywania słownictwa. Podczas każdej jednostki lekcyjnej objętej eksperymentem zaproponowano uczniom zadania z zakresu jednej z wymienionych przez badacza inteligencji. Przykładową aktywnością ukierunkowaną na rozwijanie inteligencji interpersonalnej była gra „Wesołe drzewko" firmy Voyager games, wspomagająca jednocześnie utrwalanie poznanego wcześniej słownictwa. Wymagała ona współpracy ze wszystkimi uczestnikami zajęć, wspierała zatem aktywizację uczniów wycofanych, nie zwiększając przy tym stresu związanego z możliwą porażką. Zadanie to eliminowało również elementy rywalizacji, ponieważ dzieci stanowiły jedną współpracującą drużynę. Gra polegała na wyciąganiu pojedynczych listków z drzewa, w koronie którego ukryte były owady. Zadaniem dziecka było wylosowanie obrazka z puli i spytanie grupy o jego nazwę w języku angielskim. Uczeń wykorzystywał do tego znaną, prostą strukturę. Dzięki temu nie było to zadanie demotywujące i nie wpływało na spadek skupienia uwagi. Po otrzymaniu poprawnej odpowiedzi dziecko mogło wyciągnąć jeden z listków. Wyciągnięcie fałszywego listka powodowało wystrzelenie owadów w powietrze. Zaskakująca struktura proponowanej gry pozwoliła na przełamanie rutynowych wzorców zachowań dzieci podczas zajęć i otwarcie ich na nowe doświadczenia.

\section{Podsumowanie}

Nauczanie podsystemu leksykalnego dzieci w wieku przedszkolnym ze spektrum autyzmu oraz zespołem Aspergera to złożone zagadnienie, wymagające uprzedniej analizy wielu czynników celem ich uwzględnienia podczas planowania zajęć. Należy wziąć pod uwagę nie tylko cechy rozwojowe dzieci między 3. a 6. rokiem życia, lecz także specjalne potrzeby edukacyjne takich uczniów, tj. potrzebę wizualizacji, wsparcia wzrokowo-przestrzennego czy usystematyzowanej struktury lekcji. Rozwiązaniem przynoszącym pożądane rezultaty jest 
również wprowadzenie do zajęć aktywności multisensorycznych, elementów zabawy oraz strukturyzacji aktywności. Usprawniają one współpracę nauczyciela z podopiecznymi, zapewniają możliwość lepszego opanowania nowego słownictwa, poprawiają także ogólne funkcjonowanie dziecka.

\section{BIBLIOGRAFIA}

Alexiou T., M ilton J., Roghani S. (2019), Assessing the Vocabulary Knowledge of Preschool Language Learners. Integrating Assessment into Early Language

Learning and Teaching, United Kingdom: M ultilingual M atters, s. 154-164. Cichmińska M. (2015), Bawię się więc jestem. „)ęzyki Obce w Szkole”, nr 1, s. 13-17. Dufrêne G., Chambres E., Chambres P. (2009), Le syndrome d'Asperger: atouts et particularités. „Bulletin scientifique de l'arapi”, nr 23, s. 59-65.

Gardner H. (1983), Frames of M ind: The Theory of M ultiple Intelligences. New York City: Basic Books.

Hüther G., Hauser U. (2014), Wszystkie dzieci sq zdolne. Jak marnujemy wrodzone talenty. Słupsk: Wydawnictwo Dobra Literatura.

Kic-Drgas J. (2015), Czym skorupka za młodu nasiq̨nie..., czyli kilka uwag o kształceniu interkulturowym najmłodszych. „] ęzyki Obce w Szkole”, nr 1, s. 36-42.

Komorowska H. (2005), Metodyka nauczania języków obcych. Warszawa:

Fraszka Edukacyjna.

Konderak T. (2017), Podejście wielozmysłowe w nauczaniu języków obcych dzieci. „Edukacja elementarna w teorii i praktyce”, nr 4(46), s. 97-99.

Kondrat D. (2011), Wykorzystanie inteligencji wielorakich w nauczaniu języka angielskiego. „Języki Obce w Szkole", nr 4, s. 2-10.

Kotarba-Kańczugowska M. (2015), Przedszkolak uczy się języka obcego. Kręta droga, wielka frajda. "J ęzyki Obce w Szkole”, nr 1, s. 43-49.

Medina J. (2012), Jak wychować szczęśliwe dziecko. Kraków: Wydawnictwo Literackie.

M ilton J., Alexiou T. (2009), Vocabulary size and the Common European Framework of Reference for Languages, (w:) Richards B., Daller H. M., Malvern D.D., M eara P., M ilton J., Treffers-Daller J. (red.), Vocabulary Studies in First and Second Language Acquisition. Basingstoke: Palgrave M acmillan, s. 194-211. M inistère de l'éducation nationale (2009), Scolariser les élèves autistes ou présentant des troubles envahissants du développement. Paris : CNDP. M ottron L. (2004), L'autisme: une autre intelligence. Sprimont: M ardaga. M ottron L. (2010), Que fait-on de l'intelligence autiste? „Enfance”, nr 1, s. 45-57. Piotrkowska-Skrzypek M. (2015), Kompetencje nauczyciela języka obcego w przedszkolu. „Języki Obce w Szkole", nr 1, s. 23-31. 
Pisula E. (2010), Autyzm. Przyczyny, symptomy, terapia. Gdańsk: Wydawnictwo "Harmonia".

Sowa-Bacia K. (2019), Kryteria wyboru materiałów dydaktycznych w nauczaniu języka obcego na etapie przedszkolnym. "Języki Obce w Szkole", nr 5, s. 75-79.

Tiefenthal C. (2008), Fast mapping im natürlichen L2-Erwerb. Trier: WVT.

Vanthier H. (2009), L'enseignement aux enfants en classe de langue. Paris : CLE International.

Wierzchosławska A. (2018), Nauczanie multisensoryczne w przedszkolu wraz z przykładami ćwiczeń. „J ęzyki Obce w Szkole", nr 1, s. 48-50.

Wolski A. (2013), Ograniczone, powtarzajqce się i stereotypowe wzorce zachowań, zainteresowań i aktywności u małych dzieci ze spektrum autyzmu. „Konteksty pedagogiczne”, nr 1, s. 45-63.

Wójcik-Gugulska M. (2017), Zajęcia z dużq grupq przedszkolaków mogq być świetnq zabawq̨! „Języki Obce w Szkole”, nr 2, s. 104-107.

Received: 19.03 .2021

Revised: 14.09 .2021 